$$
\text { 正会員秋月 春 雄 }{ }^{* *}
$$

\title{
Rotational Faulting Displacements and Original \\ Shapes of Veins or Seams
}

Harvo AKIZUKI

The variations of the strike and the dip of veins or seams on both sides of any faults, depend upon the original shapes of veins or seams before the dislocations and the rotary displacements of the fault walls.

The analytical results of the variations are given in most cases the direction of the rotation of the fault walls. Namely, when the variations of both the strike and the dip beyond the fault coincide with the variations in the rotary displacements, it is determined in a strong probability that the hanging wall of the fault rotates relatively in the direction of the variations, which may be caused by the rotations of the fault walls.

\section{1. 緒}

鉱脈や地層の形状は目的により一応平面として取报う ことはできるが, 厳密には平面でなく一種のねじれ面で， 鉱脈によりまた部分によつて，ねじれの程度にも差異が ある。その程度が軽微で平面に近いものもあれば，上下 左右に漸移的に変化するものもあり，あるい注不規則に 時汇は急激に変化している場合もある。

このような鉱脈や地層の形状は，断層以前に（鉣脈生 成後にこれを切る断層を考えているので) 既に本来の形 状として，すなわち既存条件としてもつていたものであ る。しかも断層の生起によりその両盤が相対的に移動し た後の同一地並は，断層以前の地並とは一般に異なるの で，鉱脈や地層が叔じれてお机ばたとえ平行移動でも， またそれ回転を伴なえばなおさら走向・傾斜の相違を 表わすことになる。

およそ一般に既存条件をもたない鉱脈は少なく，また 回転を伴なわ断層移動は一般には存在しない。したが つて断層両側における現実の相違は, 両者に程度の差は あつても，一般に既存と回転との両方の効果によるもの である。けれども任意の断層事例において，相違に与元 ている既存と回転の影響比（影響の割合）については， 走向・傾斜の対比だけでは判然としない場合がある。こ れについては別に吟味を要するが，しかし回転がいずれ の方向に行なわれたかについては，回転による変化と既 存条件との組合わせから起る事象の解析によつて, 確率 的に推定することができる。

\footnotetext{
* 昭和37年 8 月 21 日受理

** 工博 日本精鉱株式会社鈗務部長
}

\section{2. 走向の変化から推定 される回転の方向}

鉣脈や地層の走向に関する既存条件が，仮りに回転の ない断層移動の場合に断層先に現われる状態としては, 本質的に次の 3 つの場合しかない。すなわち第 1 図の平 面図に㧍いて $\mathrm{AB}$ は断層線, $\mathrm{CD}$ 桜断層の手前側の, $\mathrm{DE}$ は断層先の鉱脈であるとすると，(1) のように断層 先で左偏向する場合，(2) のように不変の場合，(3) の ように右偏向を示す場合の 3 者である。このうち (2) は 特別の場合で起る機会も稀であるから一まず考えない。 また図の $\mathrm{DE}$ は一般には右西るいは左に離れて食い違 らのであるが，走向の偏向を見易くするために $\mathrm{CD}$ の

\section{第1図}

走向の既

存条件

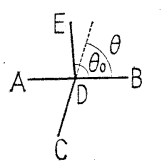

(2)

(3)

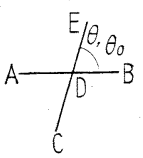

と共通に描いたものである。

さて走向の偏向係数 ${ }^{1)} f^{\prime}(0)$ の值を正数とし, 断層上 盤の右下向き回転によつて (1)，(3) の各場合が受ける 変化を (1)',(3)' で示すと第 2 図のようになる。すなわ ち $f^{\prime}(0)>0, \phi>0$ であるから断層先の走向はいずれの場 合にも左偏向して DF になり2), (1) の変化は (1)' の 一つであるが，既存条件と回転量の程度によつて (3)' のように，左偏向はするがもとの走向 $\theta$ を越えない(a) の場合と, 越えて左偏向する (b) の場合とがある。 さて任意の実例においては既存条件む任意であり，回 
$(1)^{\prime}$
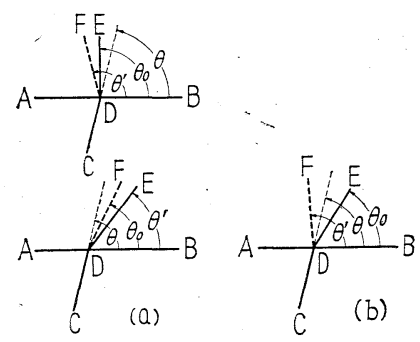

第2図 既存条件(走向)の回転に上る変化

転量も任意である。したがつて起る事象の確率は第 1 表 の上うに左偏向する場合が $75 \%$ ，右偏向の場合が $25 \%$ で ある。も乙回転の方向が右上向き $(\phi<0)$ の場合には逆 に右偏向が75\%, 左偏向が $25 \%$ になる。偏向係数 $f^{\prime}(0)$ が負数の場合にもこの比率注変らない。

この結果を逆に利用すれば, 走向の変化方向から回転 の方向を推定することができる。すなわち第 3 図 (a) の上うに断層先が左偏向している場合に, $f^{\prime}(0)$ が正(ま たは負)であれば，断層の上盤が相対的に右下向き（ま たは右上向き）に回転しており，むし（b）のように断 層先が右偏向している場合に， $f^{\prime}(0)$ が正（負）であれ ば右上向き（右下向き）回転であると推定しても，その 当たる公算は理論上 $75 \%$ ある。

しかも稀ではあるが第1図 (2)のような場合には，偏 向の方向は回転による変化の法則に従うので, かかる場 合をも考慮すれば当たる公算は $75 \%$ 以上であるといえよ う。

第1表 走向の既存条件々回転変位の確率

\begin{tabular}{l|c|c}
\hline \hline 既存条件と確率 & 移動後の偏向方向と確率 & 総 合 確 率 \\
\hline 左编向の場合(50\%) & 左偏向する (100\%) & $50 \%$ \\
\hline 右偏向の場合(50\%) & 左偏向する (50\%) & $25 \%$ \\
\hline
\end{tabular}

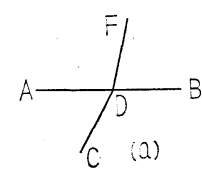

(a)

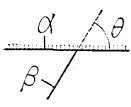

(b)

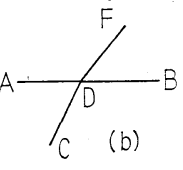

第 3 図

走向の㾫向

と回転方向

との関係

(d)
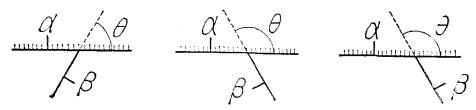

$(9)$
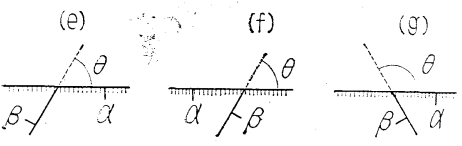

\section{3. 傾斜の変化から推定さ れる回転の方向}

断層の走向・傾斜と鉱脈や地層の走向・傾斜との関係 は第4図のような (a) (b) (c) (d) (e ) ( f ) ( g ) (h) の 8 つの場合で尽されるが, 断層の上盤が,右下向 きに回転するとき, 断層先の鉱脈の傾斜は（a）（c） (f) (h) の各場合には緩傾斜となり, その他の (b) (d) (e ) (g) の各場合には急傾斜に変化する。逆に 上盤が右上向きに回転するときは，それぞれ上記とは反 対の変化をする。

さて断層に回転運動を伴なら場合, 断層先の鉱脈の傾 斜が緩傾斜になるか，急傾斜に変化するかの区別は，正 確には $g^{\prime}(0)=-\sin \theta \sin \alpha^{12}$ の符号によつて判別され るけれども，その結果は上記第 4 図で判断した結果にほ とんど一致するので, 回転による傾斜の変化については, 回転の方向と断層の手前側における鉱脈の傾斜の方向と によつて容易に判定することができる。

さて既存条件としての傾斜が, 仮りに回転のない断層 移動の場合に断層先に現われる状態としては, 本質的に は次の 3 つの場合しかない。すなわち第 5 図の平面図に 执いて $\mathrm{AB}$ 汇断層線, $\mathrm{CD}$ 断層手前側の, $\mathrm{D}^{\prime} \mathrm{E}$ は断 層先の鉱脈であるが（1）のように断層先の傾斜が手前 側のそれよりは急傾斜を示寸場合，（2）のように無変化 の場合および (3)のように急㑯斜になる場合の 3 つであ る。この関係は断層の傾斜の方向にかかわらず，また鉱 脈の走向・傾斜の方向を問わず成り立つものである。

いま傾斜の緩急の比較を便利にするために第 5 図にお。 ける関係を, 特定の数值を用いて示せば第 6 図のように なる。ここに (2) の無変化の場合法特別の場合で, 起る 機会も稀であるから以下の考察では一まず取上げない。 また断層の傾斜の方向はどちらであつても総合結果に変 わりはないので，向こう落ちの場合で考える。
(1)

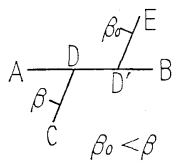

$\beta_{0}<\beta$
(2)

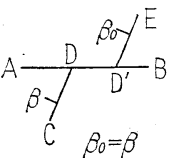

$\beta_{0}=\beta$
(3)

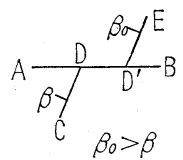

$\beta_{0}>\beta$
第 5 図 傾斜の既存条件

(1)

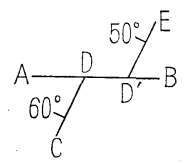

(2)

(3)
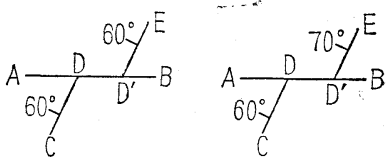

第 6 図 傾斜の既存条件の一例

第 4 図 断層と鉣脈との走向・傾斜の関係 
$(1)^{\prime}$

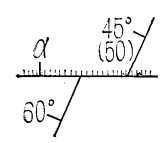

$(3)^{\prime}$

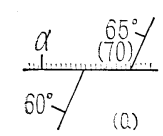

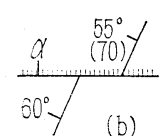

(b)
第7図

既存条件

(傾斜)

の回転に

よる変化

そこで上記の第 6 図の (1) および (3) が，断層の上盤

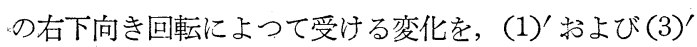
で示せば第 7 図のようになる。(1) は回転がなくても既 存条件として，断層先の傾斜が手前側に比べて緩傾斜に なる条件であるから，上盤の右下向き回転によつてさら に緩傾斜の例えば $45^{\circ}$ になる。(3) に㧍いては回転移 動以前の既存条件として, 断層先の傾斜が手前側に比心 て急傾斜である。これが右下向き回転を伴なうと緩傾斜 になるのであるが，その程度が手前側の傾斜を越えない （a）の場合と，越えて緩傾斜になる（b）の場合とが ある。

さて任意の実例に㧍いては既存条件としての傾斜む任 意であり，回転量も任意である。したがつて起る事象の 確率は第 2 表のように，緩傾斜になる場合が $75 \% ，$ 急傾 斜になるのが $25 \%$ ある。るもし鉱脈の傾斜が下向きの場 合（第 4 図 b ) には，反対に急傾斜になる場合が $75 \%$ で 緩傾斜になるのが $25 \%$ である。鉱脈の走向角 $\theta$ が鈍角の 場合でもこの比率は変わらない。断層の傾斜が手前落ち の場合でもこの比率は不変である。これを要約すれば， 傾斜に既存条件をもつ鉱脈や地層が回転断層によつて受 ける断層先の傾斜の変化は,

（i） 断層先が急傾斜になる方向に回転すると, 急傾 斜汇なる確率が $75 \%$ である。
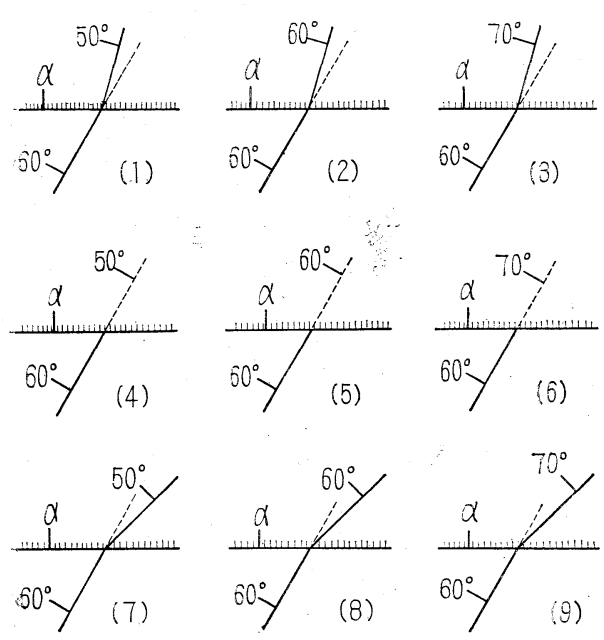

(9)
第 2 表 傾斜の既存条件と回転変位の確率

\begin{tabular}{|c|c|c|}
\hline 既存条件と確率 & 移動後の傾斜と確率 & 総合確率 \\
\hline 緩傾斜の場合(50\%) & 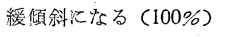 & $50 \%$ \\
\hline 急候斜の場合 $(50 \%)$ & 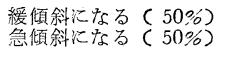 & $\begin{array}{l}25 \% \\
25 \%\end{array}$ \\
\hline
\end{tabular}

（ii）断層先が緩傾斜になる方向に回転すると，綏傾 斜になる確率が $75 \%$ である。

この結果を逆に利用すれば, 鉱脈の傾斜の変化状態か ら，断層の上盤側の相対的な回転の方向を確率的に推定 することができ，その当たる公算は理論上 $75 \%$ あ゙あ。

しかも稀ではあるが既存条件のない場合, もしく注あ つてもそれがないのと同じ結果を表わす場合には, 変化 は回転の法則に従らので，このような場合をも考慮する と上記の公算は $75 \%$ 以上であるといえよう。

\section{4. 走向・傾斜の総合変化から 推定される回転の方向}

走向・傾斜に関する既存条件が，仮りに回転のない断 層移動の場合に, 断層先に現われる姿としては, 第 8 図 の 9 個の場合で代表される。ここでは便宣上傾斜に特定 の数值を用いたが，図のように走向が左偏向している場 合 (上段), 不変の場合 (中段), 右偏向の場合 (下段) で，これに傾斜が手前側よりも緩い場合 (左側), 不変 の場合 (中の列), 急な場合 (右列) である。このうち (2) (4) (5)（6）（8）の5 つは起る公算が比較的に少な いので，害質的には四隅の（1）(3)（7):(9) の4つの 場合で代表される。

そこでこの 4 つの場合について $f^{\prime}(0)$ の值が正数で，

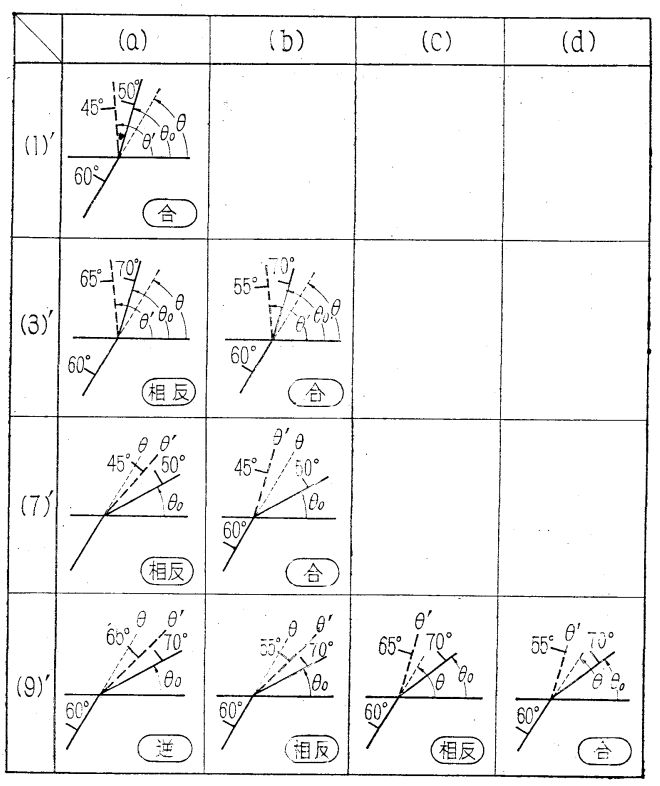

第 9 図 既存条件の回転による変化

第 8 図走向・傾斜の既存条件 
第 3 表 走向 - 傾斜の既存条件と回転変位の確率

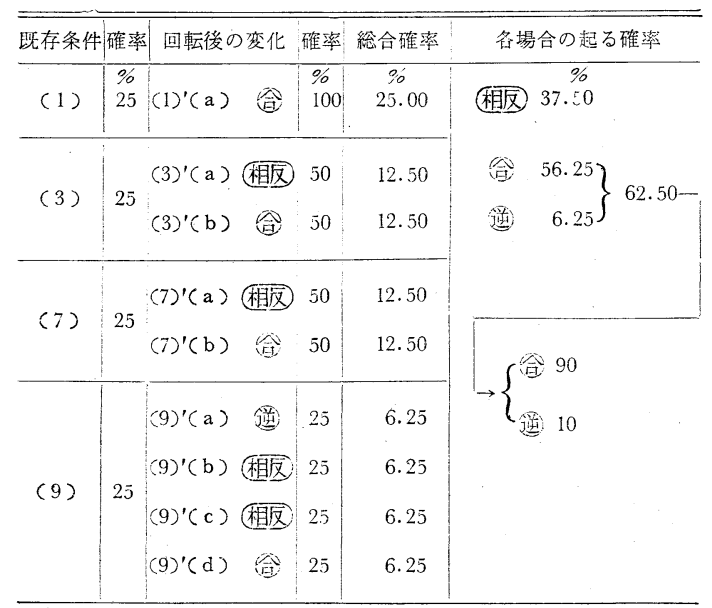

断層の上盤側が右下向き回転の場合を考えると，とにか く走向は今よりは左に，傾斜はさらに緩くなるが既存条 件と回転量の程度によつてその変化が，(1) は第 9 図の

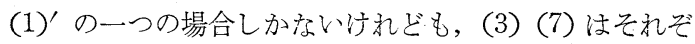
れ $(3)^{\prime}(7)^{\prime}$ の (a) (b) 各2つ记, (9) は (9)' の (a) (b) (c) (d) の4つの場合に分かれる。

この結果において走向・傾斜の変化がともに，回転に よる変化に同調するものには 目の印を，いずれか一方 だけしか合わない場合は 相四，両方とも合わないもの には迨の印をつけると図のようになる。

さて任意の実例においては既存条件も任意であり，回 転量も任意である。したがつて断層先に現われる事象の

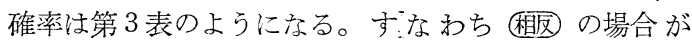
$37.5 \%$ で 目逆 合わせて $62.5 \%$ ある。回転の方向が 右上向きの場合でもこの此率は変らない。また偏向係数 $f^{\prime}(0)$ の值が負数の場合でもこの比率は不変である。断 層現象の多くの実例を調查して統計すると 相反 の事例 が約 $35 \%$ ，會の事例が約 $65 \%$ である*。これはこの確率 的推定の結果とほぼ一致する。

さて虺の現象は形式としては一定方向に回転した外観

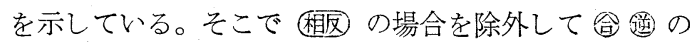
場合だけを考えると，佥の場合の起る確率は90\%で，逆 の場合は10\%に過ぎない。

この結果を逆に利用すれば，回転の方向を確率的に推 定することができる。すなわち任意の実例において走向・ 傾斜の変化が第10図のように，回転による変化の方向に 同調する合の場合には，断層の上盤側が相対的にその変 化を満足する方向へ回転していると想定しても，その当 たる公算は理論上 $90 \%$ あるといえる。

しかも稀ではあるが第 8 図の（2）(4)（6）(8）の4 つの場合には逆がない。また (5).の場合の変化は正しく
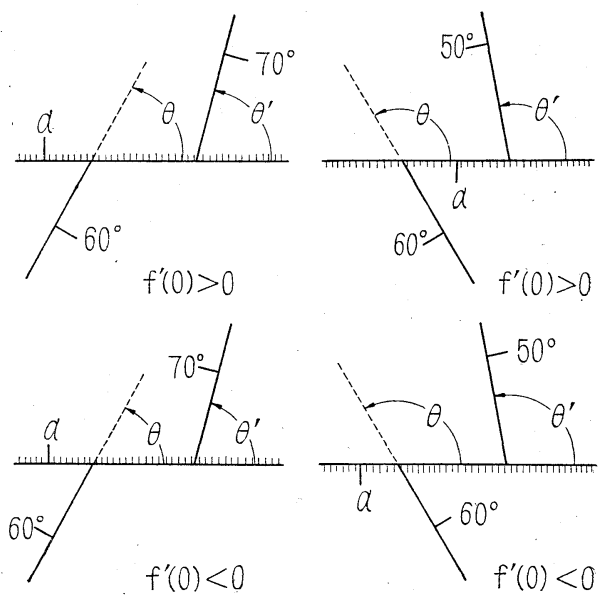

第10図 走向・傾斜の変化々回転方向之の関係

回転による変化の法則に従うので，このよう社場合をも 考慮すれば当たる公算は $90 \%$ 以上であるといえよう。

\section{5. 既存条件の判定}

まず，回転断層による鉱脈や地層の走向・傾斜の変化 の解析 ${ }^{3)}$ について簡単にのべると，断層面も鉱脈や地層 の面も一応平面とみなして, 傾斜角 $\alpha$ の断層で切られる 地層や釷脈の走向を表わす角を $\theta$, 傾斜を $\beta$ とし，この 断層が回転角 $\phi$ の回転移動によつて変化する断層先の走 向・傾斜を $\theta^{\prime}, \beta^{\prime}$ とすれば，

$$
\begin{aligned}
& \theta^{\prime}=\tan ^{-1}\left(\frac{a \sin \phi+c \cos \phi}{a \cos \alpha \cos \phi-c \cos \alpha \sin \phi+b \sin \alpha}\right) \cdots(1) \\
& \beta^{\prime}=\cos ^{-1}(-a \sin \alpha \cos \phi+c \sin \alpha \sin \phi+b \cos \alpha \cdots(2) \\
& こ こ に, \\
& a=\cos \theta \cos \alpha \sin \beta-\sin \alpha \cos \beta \\
& b=\cos \theta \sin \alpha \sin \beta+\cos \alpha \cos \beta, \quad c=\sin \theta \sin \beta
\end{aligned}
$$

さて仮りに断層先の走向・傾斜を表わす角 $\theta^{\prime}, \beta^{\prime}$ が既 知であるとき，断層の年前側の走向・傾斜を表わす角 $\theta$, $\beta$ は，上記 (1) (2) の式において $\alpha, \beta, \phi$ の符号を変 えることにより次のように表わせる。

$$
\begin{aligned}
& \theta=\tan ^{-1}\left(\frac{-a^{\prime} \sin \phi+c^{\prime} \cos \phi}{a^{\prime} \cos \alpha \cos \phi+c^{\prime} \cos \alpha \sin \phi+b^{\prime} \sin \alpha}\right) \cdots(3) \\
& \beta=\cos ^{-1}\left(-a^{\prime} \sin \alpha \cos \phi-c^{\prime} \sin \alpha \sin \phi+b^{\prime} \cos \alpha\right)(4), \\
& こ こ に, \\
& a^{\prime}=\cos \theta^{\prime} \cos \alpha \sin \beta^{\prime}-\sin \alpha \cos \beta^{\prime}
\end{aligned}
$$$$
b^{\prime}=\cos \theta^{\prime} \sin \alpha \sin \beta^{\prime}+\cos \alpha \cos \beta^{\prime}, \quad c^{\prime}=\sin \theta^{\prime} \sin \beta^{\prime}
$$
である。次に (3) から回転角 $\phi$ を求めると ${ }^{3)}$,

$$
\phi=2 \tan ^{-1}\left(\frac{l^{\prime} \pm \sqrt{k^{\prime 2}+l^{\prime 2}-m^{\prime 2}}}{k^{\prime}+m^{\prime}}\right)
$$

ここに, $k^{\prime}=a^{\prime} \cos \alpha \tan \theta-c^{\prime}, \quad l^{\prime}=c^{\prime} \cos \alpha \tan \theta-a^{\prime}$, $m^{\prime}=-b^{\prime} \sin \alpha \tan \theta$ である。また（4）から回転角 $\phi$ を求: めると, 


$$
\phi=2 \tan ^{-1}\left(\frac{q^{\prime} \pm \sqrt{p^{\prime 2}+q^{\prime 2}-r^{\prime 2}}}{p^{\prime}+r^{\prime}}\right)
$$

ここに, $p^{\prime}=a^{\prime} \sin \alpha, \quad q^{\prime}=c^{\prime} \sin \alpha, \quad r^{\prime}=b^{\prime} \cos \alpha-\cos \beta$ である。

以上の解析を参考にして既存条件の判定を試みると次 のようになる。断層先の状態については，鉣脈や地層の 既存条件としての走向・傾斜を $\theta_{0}, \beta_{0}$ とし，傾斜角 $\alpha$ の 断層の回転移動（回転角 $\phi_{0}$ ) によつて，断層先の走向・ 傾斜吕 $\theta^{\prime}, \beta^{\prime}$ に変化したものと考光ると， $\phi_{0}, \theta_{0}, \beta_{0}$ の うちいずれか一つがわかれば，他の 2 要素は計算仙よつ て知ることができる。すなわち

（1）回転角 $\phi_{0}$ がわかる場合

$$
\begin{aligned}
& \theta_{0}=\tan ^{-1}\left(\frac{-a^{\prime} \sin \phi_{0}+c^{\prime} \cos \phi_{0}}{a^{\prime} \cos \alpha \cos \phi_{0}+c^{\prime} \cos \alpha \sin \phi_{0}+b^{\prime} \sin \alpha}\right) \\
& \beta_{0}=\cos ^{-1}\left(-a^{\prime} \sin \alpha \cos \phi_{0}-c^{\prime} \sin \alpha \sin \phi_{0}+b^{\prime} \cos \alpha\right)
\end{aligned}
$$

（2）走向を表わす角 $\theta_{0}$ がわかる場合

$$
\begin{aligned}
& \phi_{0}=2 \tan ^{-1}\left(\frac{l^{\prime} \pm \sqrt{k^{\prime 2}+l^{\prime 2}-m^{\prime 2}}}{k^{\prime}+m^{\prime}}\right) \\
& k^{\prime}=a^{\prime} \cos \alpha \tan \theta_{0}-c^{\prime}, l^{\prime}=c^{\prime} \cos \alpha \tan \theta_{0}-a^{\prime} \\
& m^{\prime}=-b^{\prime} \sin \alpha \tan \theta_{0} \\
& \beta_{0}=\cos ^{-1}\left(-a^{\prime} \sin \alpha \cos \phi_{0}-c^{\prime} \sin \alpha \phi_{0}+b^{\prime} \cos \alpha\right)
\end{aligned}
$$

(3) 傾斜角 $\beta_{0}$ がわかる場合

$$
\begin{array}{r}
\phi_{0}=2 \tan ^{-1}\left(\frac{q^{\prime} \pm \sqrt{p^{\prime 2}+q^{\prime 2}-r^{\prime 2}}}{p^{\prime}+r^{\prime}}\right) \\
p^{\prime}=a^{\prime} \sin \alpha, q^{\prime}=c^{\prime} \sin \alpha, r^{\prime}=b^{\prime} \cos \alpha-\cos \beta_{0} \\
\theta_{0}=\tan ^{-1}\left(\frac{-a^{\prime} \sin \phi_{0}+c^{\prime} \cos \phi_{0}}{a^{\prime} \cos \alpha \cos \phi_{0}+c^{\prime} \cos \alpha \sin \phi_{0}+b^{\prime} \sin \alpha}\right)
\end{array}
$$

回転運動を伴なわない特別の場合には $\phi_{0}=0$ であつ て，乙たがつて $\theta_{0}=\theta^{\prime}, \beta_{0}=\beta^{\prime}$ となり，断層先の走向・ 傾斜それ自身分既存条件になる。また $\beta_{0} \doteqdot \beta^{\prime}, \theta_{0} \doteqdot \theta^{\prime}$ と なる場合には，既存条件は軽微で $\phi_{0}$ 自身がその回転角 である。

\section{6. 結言}

断層の両側における鉱脈や地層の走向・傾斜の相違は,
主として鉱脈や地層の本来の形状（既存条件）と断層の 両盤々相対的回転運動とにある。この変化を解析する々 断層両盤の相対的回転運動の方向を確率的に推定するこ とができる。すなわち

（1） 断層先の鉱脈や地層の走向が左偏向（または右 偏向）していて,

(i ) $f^{\prime}(0)>0$ であれば，この断層の上盤側は相 対的江右下向き（または右上向き）に回転している場合 が多く，その公算は75\%以上である。

(ii) $f^{\prime}(0)<0$ であれば，右上向き（または右下 向き）に回転の公算が $75 \%$ 以上である。

（2）断層の両側における鉱脈や地層の傾斜の変化は その変化を満足する方向に，断層の上盤側が相対的に回 転している場合が多く，その公算は $75 \%$ 以上である。

（3）断層先の鉱脈や地層の走向・傾斜が両方とも, 回転による変化の方向に一致するときは，断層の上盤側 が相対的にその変化を満足する方向に回転している場合 が多く，その公算は90\%以上である。

また，回転角ならでに既存条件としての走向・傾斜の 3 要素のうち, 、ずれか一つがわかれば他の 2 要素は計 算によつて知ることができる。

謝辞：この研究抒よびこれに関連した断層に関する研究に は，京都大学教授滰本清博士ならびに平松良雄博士から宏深 なる御指導を賜放つた。宋た電子計算機の操作には東京理科 大学林健児先生に，断層の実例調査に当つては多くの鉣山事 業所の方から御援助をいただいた。ここに厚く感謝の意を 表する次第である。

\section{参 考 文 献}

1) 秋月春焳：回転断層の判定法, 日本鉱業会誌, 78卷, 891 号, 昭和37 年 9 月, 633頁

2）秋月春雄：回転断層による走向の偏向方向の確率，日本鉣業会誌， 79 巻, 896, 号昭和38年 2 月, 83 頁

3) 秋月春雄: 断脈の解析, 釷山地質, Vol. 11, No. 45 46 1561, pp. 28 30. 